UDK: 349.2(4-672EU)

Biblid: 1451-3188, 20 (2021)

Izvorni naučni rad

God XX, br. 75, str. 91-106

Primljen 31.1.2021.

DOI: https://doi.org/10.18485/iipe_ez.2021.20.75.6

Odobren 10.5.2021.

\title{
POLOŽAJ ZAPOSLENIH SA PORODIČNIM DUŽNOSTIMA U EVROPSKOM PRAVU
}

\begin{abstract}
Mina KUZMINAC*
Apstrakt: Autorka se u radu bavi pitanjem položaja zaposlenih sa porodičnim dužnostima u evropskom pravu. S obzirom na to da se zaposleni sa porodičnim dužnostima suočavaju sa nizom izazova na profesionalnom planu, neophodno je da pozitivno zakonodavstvo prepozna ove izazove i poteškoće i da na adekvatan način odgovori na njih. Uspostavljanje ravnoteže profesionalnog i porodičnog života je imperativ koji mora biti na odgovarajući način manifestovan u zakonodavstvu. U tom smislu je u radu analizirano regulisanje položaja zaposlenih sa porodičnim dužnostima u nekomunitarnom i komunitarnom, odnosno pravu Evropske unije. Iako su zaposleni sa porodičnim dužnostima u određenom stepenu zaštićeni, treba podsticati garantovanje što većeg stepena zaštite u evropskom zakonodavstvu i praksi.

Ključne reči: zaposleni sa porodičnim dužnostima, ravnoteža profesionalnog i porodičnog života, jednakost polova, nekomunitarno evropsko pravo, pravo Evropske unije
\end{abstract}

\section{1) UVOD}

Pitanje ljudskog dostojanstva je neodvojivo od pitanja zaposlenja budući da posao obezbeđuje zaposlenima, tj. njihovim članovima porodice sredstva za život. ${ }^{1}$

\footnotetext{
* Autorka je student doktorskih studija Pravnog fakulteta Univerziteta u Beogradu i advokatski pripravnik u advokatskoj kancelariji Gecić Law, Beograd.

E-mail: minakuzminac96@gmail.com.

Rad je preuzet iz master rada autorke pod nazivom „Usklađenost domaćeg zakonodavstva i prakse sa evropskim standardima o pomirenju profesionalnih i porodičnih dužnosti zaposlenih", odbranjenog na Pravnom fakultetu Univerziteta u Beogradu 4. septembra 2020. godine (neobjavljen) uz odgovarajuće prilagođavanje.

${ }^{1}$ UN Committee on Economic, Social and Cultural Rights (CESCR), General Comment No. 18: The Right to Work (Art. 6 of the Covenant), 6 February 2006, E/C.12/GC/18, paragraph 1, dostupno na: https://www.refworld.org/docid/4415453b4.html, pristupljeno 29.07.2020. godine.
} 
„Počev od renesanse i uspostavljanja naučnog pogleda na svet kao dominantnog i praćenog procesa individualizacije i sekularizacije, zatvaranja pojava racionalizma i empirizma u nauci i filozofiji, kao i prosvetiteljskog duha u još širem društvenom kontekstu, pojavljivanja novovekovne teorije prirodnih prava i društvenog ugovora u političkoj teoriji i praksi, rađanja građanske klase, dakle, sveukupni procesi rađanja modernog duha i moderne epohe, ideje o univerzalnoj jednakosti svih ljudi i ličnosti, kao stvaranja sopstvene političke sudbine dobijaju značaj, mobilizatorsku snagu i masovnost."

Tradicionalna porodica je doživela brojne izmene i one su dovele do razlika u odnosu među supružnicima, u odnosu prema deci i starijim ili bolesnim članovima porodice, pa i do otvaranja niza pitanja u pogledu toga ko čini porodicu. Dalje se otvaraju pitanja u pogledu toga šta su porodične dužnosti, kao i šta podrazumeva usklađivanje obaveza profesionalnog i porodičnog života. ${ }^{3} \mathrm{U}$ tom pogledu, ravnoteža profesionalnog i porodičnog života se odnosi na objektivnu i subjektivnu angažovanost osobe u različitim sferama života. ${ }^{4}$

U tom smislu, zakonodavstvo treba da odražava ovu potrebu za postojanjem ravnoteže tako što će omogućiti zaposlenima sa porodičnim dužnostima jednak tretman u odnosu na ostale zaposlene, kao i mogućnost da uspostave ravnotežu različitih sfera života. Ovo nije samo pitanje domena važećeg prava, već i pitanje koje zadire u najdublje pore društva budući da dovodi u pitanje stereotipe i predrasude koje se tiču obavljanja porodičnih dužnosti kao „opterećujućeg” faktora za poslodavca.

Štaviše, pitanje porodičnih dužnosti otvara i pitanje jednakosti polova jer su žene te koje najčešće obavljaju porodične dužnosti. Nekadašnja hijerarhija polova (koja nije svuda nužno nekadašnja), zasnovana na predrasudama i stereotipima o „inferiornosti” žena, danas je zamenjena jednakošću, ali ostaje pitanje koliko je zaista jednakost polova prisutna u svakodnevnom životu a ne samo na papiru. Porodica, kao mikrojedinica, je odraz makroslike celokupnog društva, a s druge strane makroslika je skup niza mikroslika života.

\footnotetext{
${ }^{2}$ Dragica Vujadinović, „Rod i pravna regulative”, u Stevan Lilić (ur.), Perspektiva implementacije evropskih standarda u pravnom sistemu u Srbiji, Pravni fakultet Univerziteta u Beogradu, Beograd, 2013, str. 61-62.

${ }^{3}$ Michele Tiraboschi et al., "Final report presented to the European Comisssion", LIBRA Let's Improve Bargaining, Relations and Agreements on work and life times balance, Modena, February 2013, p. 271.

${ }^{4}$ Jeffrey H. Greenhaus, Karen M. Collins, Jason D. Shaw, "The relation between work-family balance and quality of life", Journal of Vocational Behavior, Vol. 63, 2003, p. 511.
} 


\section{2) POLOŽAJ ZAPOSLENIH SA PORODIČNIM DUŽNOSTIMA I IZAZOVI SA KOJIMA SE SUOČAVAJU}

Zaštita zaposlenih sa porodičnim dužnostima podrazumeva na prvom mestu određenje pojma zaposlenih sa porodičnim dužnostima. 0 složenosti donošenja pravnog okvira koji bi omogućio pomirenje profesionalnih i porodičnih dužnosti zaposlenih svedoči to da i samo određenje porodice, a u vezi s tim i porodičnih dužnosti, dovodi do svojevrsnih dilema. Određenje članova porodice zavisi od vremena, kulture i drugih faktora, a može varirati čak i unutar različitih delova jedne iste države. ${ }^{5}$

Konvencija Međunarodne organizacije rada broj 156 određuje pojam porodice u ovom kontekstu - pod pojmom lica sa porodičnim dužnostima podrazumevaju se „trudnice, lica koja imaju obaveze u vezi sa decom, kao i sa ostalim članovima porodice kojima je potrebna posebna briga i podrška". 6

Sve idejne i praktične promene u društvu (uključujući i promenu strukture tradicionalne porodice) neminovno dovode i do promene odnosa između zaposlenog/zaposlene i poslodavca. ${ }^{7}$ Politike su u početku bile usmerene ka tradicionalnoj porodici, ali sada je neophodno preispitivanje i izmena tih politika kako bi se prilagodile savremenom konceptu porodice. Savremeno društvo teži socijalnoj politici koja bi obezbedila usklađenost profesionalnih i porodičnih obaveza. ${ }^{8}$ Novi načini ponašanja uslovili su to da pitanje pomirenja profesionalnog i porodičnog života zadobije centralno mesto u evropskoj politici zapošljavanja, ${ }^{9}$ a promena tradicionalnih obrazaca mora da ima odgovarajući odraz na polju radnog prava. ${ }^{10}$

\footnotetext{
${ }^{5} \mathrm{UN}$ Committee on the Elimination of Discrimination Against Women, CEDAW General Recommendation No. 21: Equality in Marriage and Family Relations, 1994, paragraph 13, dostupno na: https://www.refworld.org/docid/48abd52c0.html, pristupljeno 28.07.2020. godine.

${ }^{6}$ Pogledati član broj 1 Konvencije Međunarodne organizacije rada broj 156, Službeni list SFRJ Međunarodni ugovori, broj 7/87.

${ }^{7}$ Joan C. Williams, Stephanie Bornstein, “Evolution of 'FreD': Family Responsibilities Discrimination and Developments in the Law of Stereotyping and Implicit Bias", Hastings Law Journal, Vol. 59, 2008, pp. 1311-1358.

8 "Eligibility for Parental Leave in EU Member States", European Institute for Gender Equality, Publications Office of the European Union, Luxembourg, 2020, p. 7.

9 "Combining family and full-time work", European Foundation for the Improvement of Living and Working Conditions, Dublin, 2007, p. 2, dostupno na: https://www.eurofound.europa. eu/sites/default/files/ef_files/ewco/reports/TN0510TR02/TN0510TR02.pdf, pristupljeno 21.07.2020. godine.

${ }^{10}$ Barbara Kresal, "Reconciliation of Work and Family Life - the Role of Labour Law in the Changing Economic and Social Conditions", Asociación Española de Derecho del Trabajo y de la
} 
Ukoliko se ne uspostavi ravnoteža profesionalnih i porodičnih dužnosti, neminovno dolazi do negativnih posledica na jednu ili drugu ili obe sfere. ${ }^{11}$

\subsection{POLOŽAJ I ZAŠTITA TRUDNICA I RODITELJA}

Ženama je po pravilu teže da nađu posao upravo zbog obaveza koje imaju i u porodičnoj sferi života - pronalaženje novog posla je za žene skopčano za nizom posebnih poteškoća. ${ }^{12}$ Činjenica da su žene te koje i dalje po pravilu obavljaju porodične dužnosti uslovljava to da žene traže radna mesta sa fleksibilnim oblicima zapošljavanja, što dodatno sužava izbor mogućih poslova. ${ }^{13}$ Prepreke za žene se nastavljaju i kada se zaposle, što se naročito manifestuje kroz nerazumevanje od strane poslodavaca kada je reč o porodiljskom odsustvu. ${ }^{14}$

Nadalje, briga o detetu je tekovina čovečanstva i ljudske civilizacije od samog svog nastanka. Roditelji imaju brojne obaveze prema svojoj deci uključujući novčane obaveze, brigu, negovanje, zaštitu i usmeravanje i učenje deteta kako da vodi nezavistan život. ${ }^{15}$ Briga o detetu kao porodična dužnost često dovodi do toga da roditelji (po pravilu i dalje najčešće majka deteta) bivaju diskriminisani na radnom mestu.

\subsection{BRIGA O STARIJIM ČLANOVIMA PORODICE KAO PORODIČNA DUŽNOST ZAPOSLENIH}

Iako je nesporno da pitanje zaštite trudnica i brige o maloj deci ima izuzetno veliki značaj, neophodno je posvetiti dovoljno pažnje porodičnim dužnostima koje se tiču brige o starijim članovima porodice. Briga o starijim licima podrazumeva brigu zbog starosti, usled bolesti i generalno nesposobnosti starijeg lica da vodi

Seguridad Social, Sociedad Internacional de Derecho del Trabajo y de la Seguridad Social, X Congreso Europeo de Derecho del Trabajo y de la Seguridad Social, Sevilla, 2011, p. 3.

${ }^{11}$ Julie Moschion, "Reconciling Work and Family Life: the Effect of French Family Policies", Documents de travail du Centre d'Economie de la Sorbonne v07073, Université PanthéonSorbonne (Paris 1), Centre d'Economie de la Sorbonne, 2007, p. 2.

12 "Women and Recession, How Will This Recession Affect Women at Work?", Trades Union Congress (TUC), January 2009, p. 8, dostupno na: https://www.ictu.ie/download/pdf/ womenandrecession.pdf, pristupljeno 21.07.2020. godine.

${ }^{13}$ Ibidem

${ }^{14}$ Ljubinka Kovačević, „Ravnopravnost muškaraca i žena kao bitan element dostojanstvenog zapošljavanja: prilog diskusiji o Nacrtu zakona o rodnoj ravnopravnosti”, Udruženje za radno pravo i socijalno osiguranje, Radno i socijalno pravo, vol. XXII, broj 1/2018, Beograd, 2018, str. 119-125.

${ }^{15}$ Joe Bridgeman, Heather Keating, "Introduction: Conceptualizing Family Responsibility" u J. Bridgeman, H. Keating, C. Lind (eds.), Responsability, Law and Family, Ashgate, 2008, p. 13. 
računa o sebi. ${ }^{16}$ Sama briga podrazumeva ličnu brigu (oblačenje, pranje), fizičku pomoć, pomaganje u vezi sa finansijskim obavezama, pomoć u domaćinstvu, u vezi sa poslom, posete, razgovor ${ }^{17}$ Velika većina starijih građanina koji pate od hroničnih bolesti su negovani od strane svojih članova porodice. ${ }^{18}$ Regulisanje pitanja brige o članovima porodice postaje utoliko važnije, ukoliko se uzme u obzir porast izmena demografske slike. ${ }^{19}$ Međutim, zaposleni koji brinu o starijim članovima svoje porodice su takođe često žrtve diskriminacije upravo zbog porodičnih dužnosti koje imaju.

\section{3) POLOŽAJ ZAPOSLENIH SA PORODIČNIM DUŽNOSTIMA U EVROPSKOM NEKOMUNITARNOM PRAVU}

Evropsko zakonodavstvo je prepoznalo potrebu da se zaposlenima sa porodičnim dužnostima obezbedi zaštita i faktička jednakost sa drugim zaposlenima. U tom smislu biće analizirano na koji način je položaj ove kategorije zaposlenih uređen u aktima evropskog nekomunitarnog i komunitarnog prava, odnosno prava Evropske unije.

\subsection{ZNAČAJ EVROPSKE KONVENCIJE ZA ZAŠTITU LJUDSKIH PRAVA I OSNOVNIH SLOBODA ZA ZAPOSLENE SA PORODIČNIM DUŽNOSTIMA}

Evropska konvencija za zaštitu ljudskih prava i osnovnih sloboda (u daljem tekstu: EKLJP) je usvojena 1950. godine - ona ne reguliše izričito pitanje zaštite zaposlenih sa porodičnim dužnostima. ${ }^{20}$ Međutim, EKLJP propisuje zaštitu privatnog i porodičnog života, što ima značaj za regulisanje rada zaposlenih sa porodičnim dužnostima. ${ }^{21}$

Štaviše, Evropski sud za ljudska prava jasno stoji na stanovištu da je zabranjena diskriminacija po bilo kom osnovu, što je potvrđeno u slučaju García Mateos v. Spain iz 2013. godine u kom je Evropski sud za ljudska prava doneo odluku da je Španija,

\footnotetext{
16 "Reconciliation between Work, Private and Family Life in the European Union", Eurostat European Commission, Office for Official Publications of the European Communities, Luxembourg, 2009, p. 79.

${ }^{17}$ Ibid.

${ }^{18}$ Ibid., p. 3.

${ }^{19}$ Ibid., p. 1

${ }^{20}$ Evropska konvencija za zaštitu ljudskih prava i osnovnih sloboda („,Službeni list SCG Međunarodni ugovori”, broj 9/2003, 5/2005 i 7/2005 - ispr. i „Službeni glasnik RS - Međunarodni ugovori", broj 12/2010 i 10/2015).

${ }^{21}$ Član 8 Evropske konvencije za zaštitu ljudskih prava i osnovnih sloboda.
} 
između ostalog, povredila princip zabrane diskriminacije u pogledu zaposlene sa porodičnim dužnostima. ${ }^{22}$ Protokol broj 7 EKLJP je usvojen 1984. godine i on je značajan za regulisanje porodičnih dužnosti budući da propisuje jednakost supružnika u svim pravima i obavezama privatnog prava, što podrazumeva i brigu o deci. ${ }^{23}$ Pored toga, 1964. godine je donet Evropski kodeks o socijalnoj sigurnosti, a 1990. je donet Revidirani evropski kodeks o socijalnoj sigurnosti, kodeksi koji su u velikoj meri doneti po uzoru na Konvenciju Međunarodne organizacije rada broj 102. ${ }^{24}$

EKLJP sadrži veoma opšte odredbe, što i nije začuđujuće s obzirom na širinu pitanja kojima se bavi, kao i vremenski trenutak u kom je doneta. U EKLJP je propisano to da svako ima pravo da se njegov/njen privatni i porodični život poštuje. ${ }^{25}$ Pored toga, u EKLJP se navodi da svako (ko je u godinama u kojima može da se venča) ima pravo da se venča i zasnuje porodicu. ${ }^{26}$ Nesporno je da su odredbe veoma opšte, ali ipak pokazuju ideju poštovanja porodičnog života, što se u širem smislu može tumačiti i kao zaštita porodice od svakog (pa i od poslodavca koji diskriminiše na osnovu porodičnih dužnosti).

\subsection{POLOŽAJ ZAPOSLENIH SA PORODIČNIM DUŽNOSTIMA U EVROPSKOJ SOCIJALNOJ POVELJI I REVIDIRANOJ EVROPSKOJ SOCIJALNOJ POVELJI}

Evropska socijalna povelja (ESP) je doneta 1961. godine, dok je Revidirana evropska socijalna povelja (RESP) doneta 1996. godine. ${ }^{27}$ Dodatni protokol koji

\footnotetext{
${ }^{22}$ U slučaju García Mateos v. Spain zaposlena je tražila od poslodavca fleksibilnije radno vreme s obzirom na brigu o detetu koje je imalo ispod šest godina. Poslodavac nije razumeo potrebe zaposlene i dozvolio je izmenu u radnom vremenu samo u okviru već postojećeg rasporeda. Nakon suđenja pred nacionalnim sudom Španije, slučaj je dospeo do Evropskog suda za ljudska prava gde je Španija osuđena za povredu prava na fer suđenje (povredu člana 6 Evropske konvencije o ljudskim pravima) i za povredu zabrane diskriminacije (član 14 Evropske konvencije za zaštitu ljudskih prava i osnovnih sloboda) - Case of García Mateos v. Spain, Application no. 38285/09, European Court of Human Rights, 19 February 2013, dostupno na: https://hudoc. echr.coe.int/fre\#\{\%22itemid\%22:[\%22001-116985\%22]\}, pristupljeno 10.07. 2020. godine.

${ }^{23}$ Protokol broj 7 Evropske konvencije za zaštitu ljudskih prava i osnovnih sloboda donet od strane Evropskog saveta 1984. godine (Protocol No. 7 to the Convention for the Protection of Human Rights and Fundamental Freedoms, drawn up within the Council of Europe by the Steering Committee for Human Rights and adopted by the Committee of Ministers, was opened for signature by the member States of the Council of Europe on 22 November 1984)

${ }^{24}$ Revidirani Evropski kodeks socijalne sigurnosti iz 1990. godine.

${ }^{25}$ Član 8 EKLJP.

${ }^{26}$ Član 12 EKLJP.

${ }^{27}$ Evropska socijalna povelja iz 1961. godine i Revidirana Evropska socijalna povelja doneta 1996. godine („Službeni glasnik RS - Međunarodni ugovori”, broj 42/09).
} 
ima za cilj proširenje prava garantovanih u Evropskoj socijalnoj povelji donet je 1988. godine.$^{28}$ Ono što je posebno značajno u vezi sa ovim protokolom je to da naglašava neophodnost jednakih mogućnosti i jednakog tretmana za zaposlene sa porodičnim dužnostima.

RESP je proširila zaštitu propisanu u ESP i to u pogledu zaštite lica sa porodičnim dužnostima. RESP posvećuje pažnju zaposlenima sa porodičnim dužnostima i podstiče države da usvoje neophodne mere (npr. dnevnu brigu ili odsustvo za roditelje) koje bi omogućile pomirenje profesionalnog i porodičnog života zaposlenih.

Pitanju zaštite trudnica i porodilja posvećeni su član 8 ESP i član 8 RESP. Član 8 ESP ima za cilj da obezbedi zaštitu materinstva. ${ }^{29}$ Međutim, ovaj pristup zaštite žena (koji je a priori negirao ženama pristup određenim zanimanjima) okarakterisan je kao paternalistički i zapravo (suprotno nameri) diskriminatoran. Takav pristup u članu 8 je zadržan i u RESP. Kada je reč o trajanju porodiljskog odsustva, minimum koji mora biti garantovan kad je reč o porodiljskom odsustvu je minimum od 12 nedelja u ESP, a 14 nedelja u RESP. Važno je da porodiljsko odsustvo ne može biti zamenjeno bolovanjem. Zaštita prava na porodiljsko odsustvo je potvrđena i u praksi. ${ }^{30} \mathrm{U}$ članu 8 ESP i članu 8 RESP je propisano da je tokom porodiljskog odsustva neophodno obezbediti odgovarajuću naknadu ženama, što može da se ostvari kroz različite modalitete ali mora biti garantovano. ${ }^{31}$ Odredba koja zabranjuje poslodavcu da zaposlenoj da otkaz ugovora o radu u toku porodiljskog odsustva je isto uključena s ciljem zabrane diskriminacije i „odmazde” prema zaposlenim ženama koje su na porodiljskom odsustvu. ${ }^{32}$

Član 23 RESP je prvi član koji se izričito bavi zaštitom starijih lica. RESP garantuje zaštitu starijim licima - potpisnice se obavezuju da obezbede efektivnu zaštitu i pomoć starijim licima kako bi im što duže bilo omogućeno da aktivno

\footnotetext{
${ }^{28}$ Dodatni protokol Evropske socijalne povelje iz 1988. godine.

${ }^{29}$ Council of Europe, Digest of the Case Law of the European Committee of Social Rights, 2018, p. 116.

${ }^{30}$ Sud pravde Evropske unije je u slučaju Merino Gomez v Continental Industrias del Caucho SA zaključio da činjenica da majka koristi svoje porodiljsko odsustvo nikako ne može biti smatran razlogom koji prekludira zaposlenu da koristi godišnji odmor - C-342/01 (Merino Gomez $v$ Continental Industrias del Caucho SA, C342/01, European Court of Justice, Sixth Chamber, 18 March 2004), dostupno na: https://app.croneri.co.uk/law-and-guidance/case-reports/ merino-gomez-v-continental-industrias-del-caucho-sa-c34201, pristupljeno 25.07.2020. godine.

${ }^{31}$ Council of Europe, Digest of the Case Law of the European Committee of Social Rights, op. cit., p. 116.

${ }^{32}$ Ibidem - Na strani 117. istog izvora se navodi da je u Apendiksu dodato da ova zabrana davanja otkaza nije apsolutna - „Ova odredba se ne tumači kao postavljanje apsolutne zabrane. Izuzeci mogu biti, na primer, u sledećim slučajevima: a. ako je zaposlena žena kriva za nedolično ponašanje koje opravdava prekid radnog odnosa; b. ako dotično preduzeće prestane da posluje; c. ako je rok propisan ugovorom o radu istekao".
} 
učestvuju u različitim sferama života. Ovaj član predstavlja novi pristup u garantovanju prava starijih i podstiče (i obavezuje) države da preduzmu mere kako bi se ciljevi postavljeni u ovom članu ostvarili. ${ }^{33}$ Konačno, član 27 RESP se odnosi na lica koja imaju decu ili druge članove porodice kojima je neophodna pomoć i podrška. Analiza ovog člana zahteva višeslojno razmatranje koje podrazumeva ne samo pravni okvir već i društvene okolnosti i (odsustvo) empatiju/e prema „slabijima”. Evropski komitet za socijalna prava, koji ima zadatak da nadgleda implementaciju RESP, protumačio je član 27 RESP koji se odnosi na porodične dužnosti tako da porodične dužnosti podrazumevaju brigu o deci i ostalim članovima najbliže porodice kojima je neophodna nega.

\section{4) ZAPOSLENI SA PORODIČNIM DUŽNOSTIMA U PRAVU EVROPSKE UNIJE}

\subsection{ZAPOSLENI SA PORODIČNIM DUŽNOSTIMA U PRIMARNIM IZVORIMA EVROPSKE UNIJE}

Nakon pada Berlinskog zida pitanje zaštite ljudskih prava u Evropskoj zajednici dobija naročitu aktuelnost. ${ }^{34}$ Pronalaženje ravnoteže profesionalnog i privatnog (porodičnog) života u okviru Evropske unije shvaćeno je kao ključno pitanje za dostizanje pune jednakosti polova. Pored toga, u Evropi postoji relativno visok stepen sličnosti u različitim socijalnim sistemima kada je reč o stepenu zaštite roditelja. ${ }^{35}$ Od sedamdesetih godina prošlog veka, u evropskim državama se sprovode nove politike vezane za odsustvo roditelja u vezi sa rođenjem deteta. ${ }^{36}$ Ravnoteža profesionalne i porodične sfere života se postiže u državama Evropske unije putem: fleksibilnih oblika zapošljavanja, povećanja i poboljšanja usluga koje bi omogućile pomirenje profesionalne i porodične sfere života i kroz bolju upotrebu ustanova koje bi pomogle osobama oba pola da usklade obaveze iz različitih sfera života. ${ }^{37}$

Kada je reč o principu zabrane diskriminacije, Evropska unija je donela niz dokumenata (uredbe, direktive i odluke) koji zabranjuju diskriminaciju na osnovu pola. Pored ovih dokumenata koji obavezuju države članice, Evropska unija je formulisala svoju antidiskriminatornu politiku i kroz pravno neobavezujuće akte (preporuke i mišljenja). Naročit značaj imaju direktive koje propisuju standarde

\footnotetext{
${ }^{33}$ Ibid., p. 199.

${ }^{34}$ Anna van der Vleuten, Anouka van Eerdewijk, "The Fragmented Inclusion of Gender Equality in AU-EU Relations in Times of Crises", Political Studies Review, 2020, p. 583.

35 "Eligibility for Parental Leave in EU Member States", European Institute for Gender Equality, op. cit., p. 7.

${ }^{36}$ Ibid., p. 24.

${ }^{37}$ Michele Tiraboschi et al., "Final report presented to the European Comission", op. cit., pp. 18-19.
} 
koje države članice moraju da dostignu, ali ostavljaju državi slobodu u smislu načina implementacije direktive. Osnivački ugovori Evropske unije proklamuju jednakost polova ${ }^{38} \mathrm{O}$ značaju koji je dat principu jednakosti polova u okviru Evropske unije govori i to što je ovaj princip izražen u Ugovoru o Evropskoj uniji. ${ }^{39}$

Pored toga, Ugovor o funkcionisanju Evropske unije omogućava uniji da pruži podršku i pomogne državama u aktivnostima koje se tiču pre svega jednakosti polova na tržištu rada i na samom poslu. ${ }^{40} \mathrm{U}$ tom kontekstu, važno je da Ugovor o funkcionisanju Evropske unije postavlja princip jednake zarade polova za posao iste vrednosti. ${ }^{41}$ Smatra se da je Lisabonski ugovor „krajnji rezultat dugogodišnjeg razvoja socijalne politike i politike rodne ravnopravnosti". ${ }^{42}$

Države članice Evropske zajednice su 1989. godine usvojile Povelju Zajednice o fundamentalnim socijalnim pravima radnika, koja se, između ostalog, osvrće i na pitanje potrebe usaglašavanja porodičnog i profesionalnog života. Naime, predviđajući obavezu obezbeđenja jednakog tretmana i razvijanja jednakih mogućnosti za muškarce i žene, i razrađujući u kojim domenima mora da bude intenzivirana aktivnost da bi načelo jednakosti muškaraca i žena bilo ostvareno, Povelja Zajednice o fundamentalnim socijalnim pravima radnika ističe, u kontekstu ostvarivanja jednakog tretmana muškaraca i žena, potrebu razvijanja mera koje će omogućiti muškarcima i ženama da pomire svoje profesionalne i porodične dužnosti. ${ }^{43}$ Iako izraženo na štur i načelan način, i to samo u kontekstu ostvarenja jednakog tretmana muškaraca i žena, ovo isticanje potrebe pomirenja profesionalnih i porodičnih dužnosti daje Povelji „vizionarski” karakter na ovom planu u trenutku u kom je doneta.

Pored toga, potrebno je spomenuti i Povelju osnovnih prava Evropske unije koja je doneta 2000. godine, a postala obavezujuća 2009. godine. Povelja navodi zabranu diskriminacije na osnovu pola ${ }^{44}$ i proklamuje jednakost polova u svim oblastima „uključujući zaposlenje, posao i zaradu”.45

\footnotetext{
${ }^{38}$ Konsolidovane verzije Ugovora o Evropskoj uniji i Ugovor o funkcionisanju Evropske unije (Official Journal of the European Union, C 326/2012).

${ }^{39}$ Član 3 stav 3 Ugovora o Evropskoj uniji.

${ }^{40}$ Član 153 Ugovora o funkcionisanju Evropske unije.

${ }^{41}$ Ibid., član 157.

${ }^{42}$ Zorana Antonijević, „Urodnjavanje javnih politike u Srbiji 2000-2014: politike podrške porodici u kontekstu evropskih integracija", doktorska disertacija (neobjavljena), Univerzitet u Novom Sadu, Asocijacija centara za interdisciplinarne i multidisciplinarne studije i istraživanja, Novi Sad, 2018, str. 108.

${ }^{43}$ Član 16 Povelje Evropske unije o fundamentalnim socijalnim pravima radnika iz 1989. godine.

${ }^{44}$ Član 21 Povelje osnovnih prava Evropske unije iz 2000. godine.

45 Ibid., član 23.
} 


\subsection{SEKUNDARNI IZVORI PRAVA EU I POLOŽAJ ZAPOSLENIH SA PORODIČNIM DUŽNOSTIMA}

Sekundarno pravo Evropske unije je izuzetno značajno za pitanje pomirenja profesionalnih i porodičnih dužnosti - naročito su važne direktive koje su glavno sredstvo harmonizacije prava. ${ }^{46}$ Značaj direktiva i obaveznost njihove primene u državama članicama Evropske unije je potvrđena i u sudskoj praksi. ${ }^{47}$

Direktiva o jednakom postupanju prema muškarcima i ženama doneta je 1976. godine i ona propisuje da jednakost znači da ne sme da se vrši direktna ili indirektna diskriminacija na osnovu bračnog ili porodičnog statusa. ${ }^{48}$ Direktiva 2010/18/EU koja se bavi roditeljskim odsustvom je doneta 2010. godine. Sami ciljevi Direktive su postavljeni u preambuli i glase: „poboljšati usklađivanje radnog, privatnog i porodičnog života radnih roditelja i jednakosti muškaraca i žena u pogledu mogućnosti na tržištu rada i tretmana na poslu širom Unije". ${ }^{49}$ Direktiva koja se bavi roditeljskim odsustvom iz 2010. godine je takođe usmerena ka uspostavljanju ravnoteže između roditelja u obavljanju porodičnih obaveza, i u tom smislu dozvoljava roditeljima da uzmu neophodno odsustvo usled obaveza porodičnog života. Važno je napomenuti da je u Evropskoj uniji donet niz direktiva koje su značajne za zaštitu lica sa porodičnim dužnostima iako se ne bave izričito pitanjem pomirenja profesionalne i porodične sfere života. U tom smislu, naročito su važne: Direktiva 97/81/EZ posvećena pitanju rada sa nepunim radnim vremenom; Direktiva 92/85EEZ koja se bavi zaštitom trudnica i žena na porodiljskom odsustvu;

\footnotetext{
${ }^{46}$ U vezi sa pitanjem harmonizacije prava, S. Panov navodi: „Harmonizacija u svom pojmu sadrži polisemičnost: mogućnost da jedna od strana željene jednačine bude uzor/model, da samo jedna strana jeste uzor/model, da postoje recipročni uzori, ili da susret dve pravne misli/koncepta u sinergiji rodi nejednačinu - novi kvalitet. Kao da je nesporno da dominira shvatanje harmonizacije kao vrlo uslovljenog ugovora po pristupu. Naš stav je da je opravdan razlog harmonizacije da se popravi loše, a dobro postane bolje”. Izvor: S. Panov, „Harmonizacija porodičnog prava Srbije sa pravom EU", Zbornik radova Pravnog fakulteta u Novom Sadu, 1/2013, str. 173.

${ }^{47}$ Sud pravde Evropske unije je odlučio da obaveze koje su propisane u Direktivi, a tiču se roditeljskog odsustva, moraju biti poštovane i u slučaju probnog rada - Judgement of the Court in Case C-174/16, Request for a Preliminary Ruling under Article 267 TFEU from the Verwaltungsgericht Berlin (Administrative Court, Berlin, Germany), 6. juli 2019. godine, dostupno na: http://curia.europa.eu/juris/document/document.jsf?docid=194106\&mode= req\&pageIndex=4\&dir=\&occ=first\&part=1\&text=famil $*$ doclang=EN\&cid=953845\#ctx1, pristupljeno 18.07.2020. godine.

${ }^{48}$ Član 2 Direktive 76/207/EEZ o primeni principa jednakog tretmana muškaraca i žena u pogledu pristupa zaposlenju, stručnom osposobljavanju i napredovanju i uslovima rada od 9. februara 1976. (Official Journal L039, 14 February 1976, P 0040 0042).

${ }^{49}$ Direktiva 2010/18/EU (Official Journal of the European Union, L 68/2010).
} 
Direktiva 2006/54/EZ koja je posvećena garantiji jednakosti polova; Direktiva 2010/41/EU koja garantuje jednakost polova kada je reč o samozaposlenim licima. Evropska komisija je preuzela inicijativu u bavljenju ovim pitanjem 2017. godine kada je zaključeno da Direktiva 2010/18/EU treba da bude zamenjena i da je neophodno "modernizovati i prilagoditi postojeći pravni okvir" ${ }^{50}$ Značaj i aktuelnost pitanja usaglašavanja profesionalnog i porodičnog života uslovilo je donošenje Direktive 2019/1158/EU. Direktiva je sastavni (i značajan deo) inicijative Evropske unije koja se odnosi na stub socijalnih prava. ${ }^{51}$ Interesantno je napomenuti da je u 2018. godini, godini koja je prethodila donošenju Direktive 2019/1158/EU, statistika bila takva da je „stopa zaposlenosti osoba muškog pola u Evropskoj uniji 79\%, dok je stopa zaposlenosti osoba ženskog pola 67\%, iako su žene isto, pa čak i bolje kvalifikovane". ${ }^{22}$ Zaposleni kojima je omogućeno da imaju balans profesionalnog i porodičnog života dostižu veće stope produktivnosti i više su motivisani za obavljanje posla. ${ }^{53}$ Direktiva 2019/1158/EU usvojena je u Evropskom parlamentu 4. aprila 2019. godine sa većinom od 490 glasova, dok su 82 glasa bila protiv, a 48 uzdržana. ${ }^{54}$

Navedena Direktiva je izuzetno značajna za pitanje pomirenja profesionalnog i porodičnog života ${ }^{55} \mathrm{U}$ samoj Direktivi je propisan rok od tri godine državama da je implementiraju. ${ }^{56} \mathrm{~S}$ obzirom na povezanost pitanja prava žena i pitanja ravnoteže

\footnotetext{
${ }^{50}$ Recital 9 preambule Direktive 2019/1158/EU.

51 "Rebalance" Confederation Syndicate European Trade Union, p. 7.

${ }^{52}$ Juliane Bir, "Work-Life Balance: from Legal Texts to Real Progress for Working People", ETUC, 2019.

${ }^{53}$ Tetiana Sykes, "Mental Health Europe's Analysis of the Directive on Work-Life Balance for Parents and Carers", Position Paper, Mental Health Europe, 2019, dostupno na: https://www.mhe-sme.org/analysis-of-the-directive-on-work-life-balance-for-parents-andcarers/, pristupljeno 17.07.2020. godine.

54 "Work-Life Balance: EU Parliament Voted the New Directive", Make Mother Matter, 2019, dostupno na: https://makemothersmatter.org/work-life-balance-eu-parliament-voted-thedirective-on-work-life-balance/, pristupljeno 18.07.2020. godine.

55 "Better Work-Life balance for parents and carers in the EU: Council Adopts New Rules", Council of the European Union Press Release, 13 June 2019, dostupno na: https://www.consilium. europa.eu/en/press/press-releases/2019/06/13/better-work-life-balance-for-parents-andcarers-in-the-eu-council-adopts-new-rules/, pristupljeno 10.07.2020. godine. U istom tekstu navedena je izjava ministra rada i socijalnih pitanja u Rumuniji koja glasi: „Ova Direktiva predstavlja dalji korak ka unapređenju ravnopravnosti žena i muškaraca širom Evropske unije. Trenutno muškarci imaju samo ograničene podsticaje da uzmu roditeljsko ili očinsko odsustvo ili preuzmu brigu o članovima porodice. Direktiva im pruža nove mogućnosti za to. To će smanjiti količinu neplaćenog posla od strane žena i omogućiti im više vremena za profesionalnu sferu. Takođe će doprineti otklanjanju jaza među polovima" - Marius-Constantin Budăi, ministar rada i socijalnih pitanja u Rumuniji.

${ }^{56}$ uropean Council, "Work-Life Balance for Parents and Carers - Timeline”, dostupno na: https:// www.consilium.europa.eu/en/policies/work-life-balance/, pristupljeno 30.07.2020. godine.
} 
profesionalnog i porodičnog života, Direktiva 2019/1158/EU je i odgovor na nedovoljnu zastupljenost žena na tržištu rada Evropske unije. Razlikovanje polova na tržištu ima i negativan ekonomski efekat - u okviru Evropske unije dovodi do gubitka od 370 miliona dolara godišnje. ${ }^{57}$ „Bez novih mera, verovatno je da će žene nastaviti da budu u ekonomski nepovoljnijem položaju zbog materinstva tokom svoje karijere i penzije, naročito zbog nejednake podele brige i obaveza domaćinstva."58

Cilj Direktive 2019/1158/EU je uveden kroz pozivanje na član 153 Ugovora o funkcionisanju Evropske unije, koji kaže da Evropska unija podržava države članice u aktivnostima koje se tiču jednakosti polova u mogućnosti i tretmanu na tržištu rada. Konfederacija evropskih sindikata je podržala donošenje ove Direktive, ali smatra da je neophodno ispuniti viši standard u odnosu na onaj koji je postavljen u Direktivi. ${ }^{59}$ Sama direktiva Evropske unije broj 2019/1158/EU u okviru „definicija” određuje šta se smatra porodičnim dužnostima u svrhu primene ove direktive kao i na koja lica se primenjuje. ${ }^{60} \mathrm{I}$ u Direktivi 2019/1158/EU propisana je zabrana diskriminacije. Takođe, u Direktivi je propisano: „Države članice će preduzeti neophodne mere za zabranu manje povoljnog postupanja sa radnicima na osnovu toga što su zatražili ili su uzeli dopust, predviđen u članovima 4, 5 i 6, ili odmora sa posla predviđenih u članu 7, ili su izvršili prava predviđena članom 9." Direktiva postavlja minimum standarda, ali socijalni partneri pregovorima mogu da postave i viši standard od onog postavljenog u samoj Direktivi. Direktivu prate mere koje imaju za cilj da usmere i pomognu državama s ciljem postizanja standarda iz (i višeg od) propisanog u Direktivi. ${ }^{61}$ Direktiva uvodi nove obaveze za države članice i te

57 "EU Work-Life Balance Directive Comes into Force", EUbusiness, dostupno na: https://www.eu business.com/news-eu/work-life-balance.19en, pristupljeno 18.07.2020. godine.

58 "Strategic Engagement for Gender Equality 2016-2019", European Commsion, European Union, 2015, p. 8.

59 "Rebalance" Confederation Syndicate European Trade Union, op. cit., p. 8. U istom tekstu je navedeno sledeće: „Konfederacija evropskih sindikata je izrazila žaljenje što neki od važnih elemenata, poput plaćanja roditeljskog odsustva, barem na nivou bolovanja i potpune neprenosivosti odsustava između roditelja, nisu uređeni u Direktivi. Takođe je izrazila kritiku u pogledu toga da Direktiva nije dala pravo na fleksibilno radno vreme; umesto toga direktiva samo predviđa pravo da se to traži".

${ }^{60}$ U Direktivi 2019/1158/EU se navodi: „Odsustvo za očeve - odsustvo sa posla za očeve ili, ako je to priznato nacionalnim zakonom, za ekvivalentne druge roditelje, u slučaju rođenja deteta za potrebe pružanja nege; Roditeljsko odsustvo - odsustvo sa posla za roditelje na osnovu rođenja ili usvajanja deteta, radi brige o tom detetu; Odsustvo negovatelja - odsustvo sa posla radi pružanja lične nege ili podrške rođaku ili osobi koja živi u istom domaćinstvu kao i zaposleni i kojoj je potrebna značajna nega ili podrška usled ozbiljnog medicinskog razloga, kako ga je definisala svaka država članica".

61 "EU Work-Life Balance Directive Enters into Force", European Commission, News, 22/08/2019, dostupno na: https://ec.europa.eu/social/main.jsp?catId=89\&furtherNews= yes\&langId=en\&newsId=9438, pristupljeno 23.07.2020. godine. 
obaveze podrazumevaju: uvođenje odgovarajućih sankcija za nepoštovanje odredaba kada Direktiva bude implementirana i uvođenje promene u nacionalno zakonodavstvo i staranje o tome da socijalni partneri sprovode te promene.

Direktiva 2019/1158/EU sastoji se iz dva dela koji se odnose na: odsustvo za očeve, roditelje i negovatelje i fleksibilne oblike zaposlenja za roditelje i negovatelje. Direktiva ima za cilj: „veću podršku uspostavljanju ravnoteže profesionalnog i porodičnog života za roditelje i negovatelje, ohrabrivanje ravnopravnije podele roditeljskog odsustva između osoba muškog i ženskog pola, usmeravanje pažnje ka nedovoljnoj zastupljenosti žena na tržištu rada".62 S obzirom na razlike u stepenu zaštite koje postoje u okviru država Evropske unije, promene koje su uvedene Direktivom su manje ili veće, ali je nesporno da Direktiva donosi promenu na bolje. ${ }^{63}$ Uvođenjem novina iz Direktive i novina u pogledu odsustva i fleksibilnih modaliteta zaposlenja, doprinosi se blagostanju brojnih zaposlenih. ${ }^{64}$ Uspostavljanje ravnoteže između profesionalnog i porodičnog života nije samo imperativ savremenog društva, već i način da se postigne veća produktivnost i brži razvoj društva.

U tom kontekstu, treba obratiti pažnju i na rad sa nepunim radnim vremenom. Istina je da su mnoge prednosti rada sa nepunim radnim vremenom, ali treba uzeti u obzir i to da se nepuno radno vreme percipira kao znak lošije pozicije na tržištu rada. Paradoksalno, nepuno radno vreme nekad može da proizvede više problema u odnosu na prednosti koje postoje za roditelje koji brinu o deci. ${ }^{65}$ Odsustvo za roditelja radi brige o detetu je odredba koja ima za cilj da zaštiti roditelje koji brinu o deci bez straha od gubitka posla. ${ }^{66}$ Iako je gubitak posla težak za svaku osobu,

62 "Employment, Social Affairs \& Inclusion", European Commission, News, 2019, dostupno na: https://ec.europa.eu/social/main.jsp?catId=89\&furtherNews=yes\&langId=en\&newsId=9438, pristupljeno 31.07.2020. godine.

63 "New EU Directive Seeks to Address Employees' Work-Life Balance", International Bar Association, 2019, dostupno na: https://www.ibanet.org/Article/NewDetailPreview.aspx? ArticleUid=9ea8ade6-022a-4f0b-bba2-6860ad994191, pristupljeno 08. 07. 2020. godine. U tom smislu, interesantno je pomenuti neke od stavova povodom Direktive 2019/1158/EU koji se navode u istom tekstu, npr: „Potencijalna ideja je da se uključi minimalan iznos roditeljskog odsustva na koji zaposleni treba da imaju pravo, osim ako bi to ozbiljno remetilo dobro funkcionisanje poslodavca. Međutim, ovo je verovatno rešenje koje seže predaleko" - Jaouad Seghrouchni, advokat u Rutgers \& Posch.

${ }^{64}$ Tetiana Sykes, "Mental Health Europe's Analysis of the Directive on Work-Life Balance for Parents and Carers”, op. cit. U istom tekstu autorka navodi sledeće: „Najnoviji podaci Evropske komisije i Organizacije za ekonomsku saradnju i razvoj (OECD) procenjuju da troškovi vezani za probleme mentalnog zdravlja na tržištu rada uslovljavaju nižu stopu zaposlenosti i smanjenu produktivnost što je dovelo do gubitka od 240 milijardi evra (1,6\% BDP-a od svih 28 država članica EU) u 2015. godini”.

65 "Combining Family and Full-time work", op. cit., p. 3.

66 "Eligibility for Parental Leave in EU Member States", European Institute for Gender Equality, op. cit., p. 7. 
posledica gubitka može imati naročito velike posledice za žene koje su i dalje, po pravilu, češće zaposlene na nisko plaćenim poslovima a zadužene za obavljanje porodičnih dužnosti. ${ }^{67}$ Dodatne mere za obezbeđivanje ravnoteže donose dobrobit roditeljima i negovateljima, ali i kompanijama koje ih zapošljavaju.$^{68}$ Interesantno je da u Direktivu 2019/1158/EU nije uključen i predlog o odsustvu za majke. Ženski lobi Evropske unije smatra da je Direktiva trebalo da sadrži odredbe koje bi ojačale pravo majke na odsustvo. ${ }^{69}$

Na osnovu navedenog, može se zaključiti da je Direktiva 2019/1158 EU veliki i značajan korak Evropske unije povodom zaštite zaposlenih sa porodičnim dužnostima. Ipak, i kada je reč o ovoj direktivi, ali i o svim ranije navedenim evropskim aktima, potrebno je naglasiti da se praksa često nalazi u manjem ili većem raskoraku sa onim što je propisano. Stoga je neophodno usaglasiti praksu u kojoj zaposleni sa porodičnim dužnostima često bivaju diskriminisani sa evropskim propisima.

\section{5) ZAKLJUČNA RAZMATRANJA}

Na osnovu rečenog može se zaključiti da je pitanje porodičnih dužnosti, tj. zaposlenog/zaposlene sa porodičnim dužnostima veoma složeno i to na više načina. Samo definisanje zaposlenih sa porodičnim dužnostima može izazvati različite dileme - da li se porodica karakteriše kroz krvne veze ili su možda emotivne ili psihološke veze te kojima treba dati prednost. Kada se uspostavi konsenzus povodom toga ko se smatra članom porodice u kontekstu obavljanja porodičnih dužnosti uz pomoć međunarodnih dokumenata, otvara se niz drugih pitanja. $\mathrm{Na}$ neka pitanja su odgovori dati, na neka nisu, ali i svaki odgovor uslovljava niz novih pitanja o potencijalnom boljem rešenju.

Kada je reč o evropskom pravu ono postavlja standarde i doprinosi zaštiti lica sa porodičnim dužnostima. Evropsko komunitarno pravo nema u osnivačkim ugovorima odredbe koje se izričito tiču pitanja pomirenja profesionalne i porodične sfere života, ali postavlja temelje garantije ljuskih prava u Evropskoj uniji, što je značajno za dalji i detaljniji razvoj regulative Evropske unije. Naročito su značajne direktive budući da su one glavno sredstvo harmonizacije. U radu je pomenuto više direktiva kroz koje se može zaključiti da je u Evropskoj uniji posebna pažnja (i briga) posvećena pojedinim porodičnim dužnostima, ali je značaj Direktive 2019/1158/EU u tome što se bavi ukupnošću porodičnih dužnosti - kao što je objašnjeno, ona unosi novine u vidu odsustva za očeve i odsustva za roditelje.

\footnotetext{
67 “Women and Recession, How Will this Recession Affect Women at Work?", op. cit., p. 7.

68 "Rebalance" Confederation Syndicate European Trade Union, op. cit., p. 13.

69 "Work-Life Balance Directive, The EWL Assessment of the Recently Adopted Directive on WorkLife Balance for parents and carers", European Women's Lobby (EWL), 2019, Brussels, dostupno na: https://www.womenlobby.org/IMG/pdf/wlb_ewl_assessment_2019-2.pdf, pp. 3-5.
} 
Život nije jednodimenzionalan i prema tome ni od zaposlenog se ne može zahtevati da je profesionalna sfera jedina sfera postojanja i razvoja. Pomirenje različitih sfera života nije samo nužno i u skladu sa standardima jednakog tretmana, već podstiče i samog zaposlenog, što ima pozitivan efekat za radno mesto i poslodavca. Put ka efektivnijem ostvarivanju zaštite (kako na papiru tako i u praksi) nije lak, ali svaki korak je značajan i vodi ka pravednijem i boljem svetu (ili makar svetu u kom je moguće uspostaviti ravnotežu između profesionalne i porodične sfere života).

\section{6) LITERATURA}

Antonijević, Zorana, „Urodnjavanje javnih politike u Srbiji 2000-2014: politike podrške porodici u kontekstu evropskih integracija", doktorska disertacija (neobjavljena), Univerzitet u Novom Sadu, Asocijacija centara za interdisciplinarne i multidisciplinarne studije i istraživanja, Novi Sad, 2018.

Bir, Juliane, "Work-Life Balance: from Legal Texts to Real Progress for Working People", ETUC, 2019.

Bridgeman, Jo, Keating, Heather, "Introduction: Conceptualizing Family Responsibility" in Bridgeman Jo, Keating Heather, Lind Craig (eds.), Responsability, Law and Family, Ashgate, 2008, pp. 1-17.

Greenhaus, Jeffrey H., Collins, Karen M., Shaw, Jason D., "The Relation between Work-Family Balance and Quality of Life", Journal of Vocational Behavior, Vol. 63, 2003, pp. 510-531.

Kovačević, Ljubinka, „Ravnopravnost muškaraca i žena kao bitan element dostojanstvenog zapošljavanja: prilog diskusiji o Nacrtu zakona o rodnoj ravnopravnosti", Udruženje za radno pravo i socijalno osiguranje, Radno $i$ socijalno pravo, vol. XXII, broj 1/2018, Beograd, 2018, str. 97-144.

Kresal, Barbara, "Reconciliation of Work and Family Life - the Role of Labour Law in the Changing Economic and Social Conditions", Asociación Española de Derecho del Trabajo y de la Seguridad Social, Sociedad Internacional de Derecho del Trabajo y de la Seguridad Social, X Congreso Europeo de Derecho del Trabajo y de la Seguridad Social, Sevilla, 2011.

Moschion, Julie, "Reconciling Work and Family Life: the Effect of French Family Policies", Documents de travail du Centre d'Economie de la Sorbonne v07073, Université Panthéon-Sorbonne (Paris 1), Centre d'Economie de la Sorbonne, 2007.

Panov, Slobodan, „Harmonizacija porodičnog prava Srbije sa pravom EU”, Zbornik radova Pravnog fakulteta u Novom Sadu, 1/2013, str. 171-192.

Sykes, Tetiana, "Mental Health Europe's Analysis of the Directive on Work-Life Balance for Parents and Carers", Position Paper, Mental Health Europe, 2019. 
Tiraboschi, Michele, et al., "Final report presented to the European Comisssion", LIBRA Let's Improve Bargaining, Relations and Agreements on work and life times balance, Modena, 2013.

Van der Vleuten, Anna, Van Eerdewijk, Anouka, "The Fragmented Inclusion of Gender Equality in AU-EU Relations in Times of Crises", Political Studies Review, 2020, pp. 576-591.

Vujadinović, Dragica, „Rod i pravna regulative”, u Stevan Lilić (ur.), Perspektive implementacije evropskih standarda u pravni sistem Srbije, Pravni fakultet Univerziteta u Beogradu, Beograd, 2013, str. 60-80.

Williams, Joan C., Bornstein, Stephanie, "Evolution of "FReD": Family Responsibilities Discrimination and Developments in the Law of Stereotyping and Implicit Bias", Hastings Law Journal, vol. 59, 2008, pp. 1311-1358.

\section{THE POSITION OF EMPLOYEES WITH FAMILY DUTIES IN EUROPEAN LAW}

Summary: The author deals with the issue of the position of employees with family in European law. Given that employees with family duties face a number of challenges in their professional lives, it is necessary for legislation to recognise these challenges and difficulties and to adequately respond to them. Establishing a balance between professional and family life is an imperative that must be adequately reflected in the legislation. In that sense, the paper analyses the regulation of the position of employees from family duties in European Community and non-Community law, i.e., the law of the European Union. Although this category of employees is to some extent protected, the guarantee of the highest possible level of protection in European legislation and practice should be encouraged.

Keywords: employees with family duties, work-life balance, gender equality, nonCommunity European law, European Union law. 